\title{
Karakteristik dan Perilaku Berisiko Pasangan Infertil di Klinik Fertilitas dan Bayi Tabung Tiara Cita Rumah Sakit Putri Surabaya
}

\author{
Najakhatus Sa'adah, Windhu Purnomo \\ Departemen Biostatistika dan Kependudukan \\ FKM Universitas Airlangga \\ Jl. Mulyorejo Kampus C UNAIR 60115 \\ Alamat Korespondensi: \\ Najakhatus Sa'adah \\ najakaktus@gmail.com
}

\begin{abstract}
Infertility is a condition in which someone unable to conceive and give birth after one year of regular coital activity without contraception. The aim of this study was to describe respondents characteristic of infertile couple and risk factors of the incidence of infertility, which are smoking, alcohol consumption and obesity on the incidence of infertility. This study used descriptive analysis method. Sample of this study were all patients of infertile couples in the Fertility Clinic and In Vitro Fertilization Tiara Cita during the period from November to December 2015. They were 83 couples as the samples. The data of this study were collected from questionnaires as primary data and general at clinic as secondary data. Analysis of data through cross tabulation. The results showed that respondents was conduct risk behavior (39,8 percent) to smoke, alcohol consumption (27,7 percent), and obesity (40,9 percent ). Based on this data showed that the majority of couples infertil at the clinic was behave that the risk is one factor of infertility. The need for increased knowledge about risk factors and for couples who had obesity to applied a pattern of a healthy diet by keeping weight ideal.
\end{abstract}

Keywords: smoking, alcohol consumption, obesity and infertility

\begin{abstract}
ABSTRAK
Infertilitas merupakan kondisi pada sesorang yang tidak memiliki kemampuan untuk mengandung dan melahirkan setelah satu tahun aktivitas koitus secara teratur tanpa kontrasepsi. Penelitian ini bertujuan untuk mengetahui gambaran kebiasaan merokok, konsumsi alkohol dan obesitas pada kejadian infertilitas Metode yang digunakan adalah analisis deskriptif. Sampel dalam penelitian ini adalah seluruh pasien pasangan infertil di Klinik Fertilitas dan Bayi Tabung Tiara Cita periode Nopember-Desember 2015. Jumlah sampel yang didapat sebanyak 83 pasangan. Pengumpulan data menggunakan data primer yaitu data yang diperoleh melalui kuesioner sedangkan data sekunder yaitu data umum klinik. Analisis data yang digunakan adalah univariat untuk melihat distribusi frekuensi. Responden sebagian mengalami infertilitas primer (77,1 persen), Responden melakukan perilaku berisiko sebesar (39,8\%) untuk kebiasaan merokok, mengonsumsi alkohol (27,7 persen), dan obesitas (40,9 persen). Berdasarkan data tersebut menggambarkan bahwa sebagian responden pasangan infertil di klinik tersebut berperilaku berisiko yang menjadi salah satu faktor kejadian infertilitas. Dibutuhkan pengetahuan yang lebih baik tentang beberapa perilaku berisiko serta pada pasangan suami istri untuk menerapkan pola diet yang sehat dengan menjaga berat badan yang ideal.
\end{abstract}

Kata kunci: merokok, konsumsi alkohol, obesitas dan infertilitas

\section{PENDAHULUAN}

Infertilitas adalah ketidakmampuan untuk hamil sesudah 12 bulan atau enam bulan pada wanita berusia lebih dari 35 tahun tanpa menggunakan kontrasepsi dan melakukan hubungan seksual aktif (Kusmiran, 2013).
Infertilitas memberikan dampak bagi pasangan suami istri yang mengalaminya, selain menyebabkan masalah medis, juga berdampak pada masalah psikologis bahkan perekonomian. Secara garis besar, pasangan yang mengalami infertilitas akan menjalani proses panjang, di mana proses ini dapat menjadi beban fisik dan 
psikologis bagi pasangan infertilitas (Koes, 2014).

Data Organisasi Kesehatan Dunia (WHO) tahun 2010 menyebutkan bahwa pasangan suami istri yang mengalami infertilitas sebanyak 25 persen dan menunjukkan bahwa 64 persen penyebab berada pada istri dan sebesar 36 persen diakibatkan adanya kelainan pada suami (Addy, 2012).

Badan Pusat Statistik (BPS) 2011 menyebutkan dari total 237 juta penduduk Indonesia, terdapat kurang lebih 39,8 juta wanita usia subur, namun $10-15$ persen diantaranya infertil. Ariyadi (2006), menjelaskan bahwa terdapat dua faktor yang mempengaruhi kejadian infertilitas, yaitu internal dan eksternal. Faktor internal antara lain kelainan hormonal, kista ovarium dan tumor. Faktor eksternal antara lain usia, kebiasaan merokok, alkohol juga mempengaruhi kesuburan.

Obesitas merupakan masalah kesehatan masyarakat yang serius karena obesitas berperan dalam meningkatkan morbiditas dan mortalitas. Prevalensi obesitas populasi dewasa di seluruh dunia pada tahun 2005 mencapai 400 juta jiwa (WHO, 2011). Berdasarkan hasil Riset Kesehatan Dasar (Riskesdas) tahun 2010, angka kejadian obesitas di Indonesia pada kelompok usia 18 tahun ke atas dengan persentase terbanyak pada wanita yaitu sebanyak 15,5 persen, dibandingkan laki-laki yaitu sebesar 7,8 persen. Pada tahun 2013, prevalensi obesitas perempuan dewasa ( $>18$ tahun) 32,9 persen, naik 18,1 persen dan laki-laki sebanyak 19,7 persen meningkat dari tahun sebelumnya (13,9 persen) (Riskesdas, 2013).

Pasangan usia subur yang keduanya mengalami obesitas memiliki risiko 2.74 kali untuk mengalami infertilitas dibandingkan dengan pasangan usia subur yang tidak obesitas. Bukan hanya obesitas, merokok juga dapat menyebabkan infertilitas. Sebuah penelitian oleh Saleh (2002), tentang efek merokok terhadap timbulnya seminal oxidative stres pada pria yang mengalami infertil berhasil membuktikan bahwa merokok memiliki efek yang merugikan terhadap kualitas sperma, terutama konsentrasi sperma, motilitas, dan morfologi.

Kebiasaan merokok pada perempuan juga menurunkan kemungkinan hamil sebesar 30 persen. Zat nikotin yang ada dalam tembakau dapat mempengaruhi kadar hormon dalam tubuh. Nikotin juga mengandung racun yang berbahaya bagi embrio. Perempuan perokok berat cenderung sulit hamil, mengalami kehamilan ektopik atau keguguran (Ambarwati, 2009).

Data di Klinik Fertilitas dan Bayi Tabung Tiara Cita RS. Putri Surabaya tahun 2013 menyebutkan jumlah kunjungan pasien sebanyak 186 pasien dan meningkat pada tahun berikutnya sebanyak 298 kunjungan. Pada bulan Januari-September tahun 2015 jumlah kunjungan sebanyak 342 kunjungan.

Berdasarkan studi sebelumnya di beberapa wilayah, tentang kaitan antara merokok, konsumsi alkohol dan obesitas pada kejadian infertilitas, maka dilakukan penelitian tentang faktor risiko tersebut berdasarkan jenis infertilitas.

\section{METODE PENELITIAN}

Penelitian ini menggunakan analisis deskriptif. Populasi penelitian adalah pasangan infertil di Klinik Fertilitas dan Bayi Tabung Tiara Cita RS. Putri Surabaya dan sampel yang diambil seluruh pasien pasangan infertil periode Nopember-Desember 2015 yaitu sebanyak 83 responden.

Variabel yang di gunakan adalah kebiasaan merokok, konsumsi alkohol dan obesitas. Pengumpulan data dalam penelitian ini menggunakan data primer dan data sekunder. Data primer yaitu data yang diperoleh melalui wawancara secara langsung dengan menggunakan kuesioner yang diberikan kepada responden. Data sekunder adalah data jumlah kunjungan pada tahun sebelumnya yang diperoleh dari Klinik Fertilitas dan Bayi Tabung Tiara Cita RS. Putri Surabaya.

Data yang diperoleh diolah kemudian di analisis untuk melihat gambaran distribusi frekuensi dan hasilnya akan disajikan dalam bentuk narasi dan tabulasi silang sesuai dengan teori yang terkait.

\section{HASIL PENELITIAN}

Responden dalam penelitian ini adalah seluruh pasangan infertil yang datang ke klinik fertilitas periode Nopember-Desember 
2015 dengan total jumlah responden sebanyak 83 pasangan. Adapun hasil analisis karakteristik responden disajikan sebagai berikut:

\section{KARAKTERISTIK}

\section{Jenis Infertilitas}

Infertilitas dalam penelitian ini dibagi menjadi dua kelompok yaitu infertilitas primer dan sekunder. Infertilitas primer adalah ketika Pasangan Usia Subur (PUS) yang telah menikah lebih dari satu tahun melakukan hubungan seksual secara aktif tanpa usaha pencegahan, tetapi belum juga terjadi kehamilan, atau belum pernah melahirkan anak hidup dan infertilitas sekunder adalah jika istri pernah hamil, namun kemudian tidak terjadi kehamilan lagi walaupun bersenggama tanpa usaha kontrasepsi. Sementara itu, hasil penelitian menunjukkan bahwa dari 83 responden, sebagian besar $(77,1$ persen $)$ mengalami infertilitas primer (Tabel 1.).

\section{Kelompok Usia}

Hasil Tabel 2 menginformasikan bahwa kelompok usia responden lebih dari separuh $(57,8$ persen) berusia antara 26-35 tahun.

\section{Jenis Pekerjaan}

Hasil wawancara menunjukkan bahwa jenis pekerjaan dari 83 responden yang terbanyak adalah swasta sebanyak 39 (47 persen) dan yang terendah adalah PNS/TNI/POLRI sebanyak 15 pasangan (18,1 persen).

Tabel 1. Distribusi Jenis Infertilitas

\begin{tabular}{lcc}
\hline $\begin{array}{l}\text { Jenis } \\
\text { Infertilitas }\end{array}$ & Frekuensi & Persentase \\
\hline Primer & 62 & 77,1 \\
Sekunder & 21 & 22,9 \\
\hline Total & $\mathbf{8 3}$ & $\mathbf{1 0 0}$ \\
\hline
\end{tabular}

Tabel 2. Distribusi Kelompok Usia Responden.

\begin{tabular}{lcc}
\hline Usia & Frekuensi & Persentase \\
\hline $15-25$ & 6 & 7,2 \\
$26-35$ & 48 & 57,8 \\
$36-45$ & 29 & 34,9 \\
\hline Total & $\mathbf{8 3}$ & $\mathbf{1 0 0}$ \\
\hline
\end{tabular}

Tabel 3. Distribusi Frekuensi Jenis Pekerjaan

\begin{tabular}{lcc}
\hline Jenis Pekerjaan & Frekuensi & Persentase \\
\hline Swasta & 39 & 47 \\
Wiraswasta & 29 & 34,9 \\
PNS/TNI/POLRI & 15 & 18,1 \\
\hline Total & $\mathbf{8 3}$ & $\mathbf{1 0 0}$ \\
\hline
\end{tabular}

Tabel 4. Distribusi Frekuensi Pendidikan Terakhir

\begin{tabular}{lcc}
\hline $\begin{array}{l}\text { Pendidikan } \\
\text { terakhir }\end{array}$ & Frekuensi & Persentase \\
\hline SD & - & - \\
SMP & 1 & 1,2 \\
SMA & 27 & 32,5 \\
PT & 55 & 66,3 \\
\hline Total & $\mathbf{8 3}$ & $\mathbf{1 0 0}$ \\
\hline
\end{tabular}

Tabel 5. Distribusi Frekuensi Kebiasaan Merokok Responden

\begin{tabular}{lcc}
\hline Kebiasaan Merokok & Frekuensi & Persentase \\
\hline Ya & 33 & 39,8 \\
Tidak & 50 & 60,2 \\
\hline Total & $\mathbf{8 3}$ & $\mathbf{1 0 0}$ \\
\hline
\end{tabular}

\section{Pendidikan Terakhir}

Mayoritas (66,3 persen) pendidikan terakhir responden di Klinik fertilitas dan bayi tabung Tiara Cita adalah di PT (Perguruan Tinggi) .

\section{Perilaku Berisiko}

Pada penelitian ini akan dikaji beberapa perilaku yang berisiko menjadi salah satu penyebab infertilitas diantaranya adalah kebiasaan merokok, konsumsi alkohol dan obesitas.

\section{Kebiasaan Merokok}

Distribusi frekuensi kebiasaan merokok responden di Klinik Fertilitas dan Bayi Tabung Tiara Cita periode Nopember-Desember 2015.

Hasil penelitian menunjukkan bahwa, lebih dari separuh $(60,2$ persen) total responden tidak memiliki kebiasaan merokok. 
Tabel 6. Distribusi Frekuensi Kebiasaan Merokok Berdasarkan Usia

\begin{tabular}{rrrr}
\hline \multirow{2}{*}{ Usia } & \multicolumn{2}{c}{ Kebiasaan merokok } & \multirow{2}{*}{ Yrekuensi } \\
\cline { 2 - 4 } & \multicolumn{1}{c}{ Ya } & \multicolumn{1}{c}{ Tidak } & \\
\hline $15-25$ & $1(3,1 \%)$ & $5(10 \%)$ & $6(7,3 \%)$ \\
$26-35$ & $15(45,4 \%)$ & $33(66 \%)$ & $48(57,8 \%)$ \\
$36-45$ & $17(51,5 \%)$ & $12(24 \%)$ & $29(34,9 \%)$ \\
\hline Total & $\mathbf{3 3 ( 3 9 , 7 \% )}$ & $\mathbf{5 0 ( 6 0 , 3 \% )}$ & $\mathbf{8 3 ( 1 0 0 \% )}$ \\
\hline
\end{tabular}

Tabel 7. Distribusi Frekuensi Usia Pertama Kali Responden Merokok

\begin{tabular}{lcc}
\hline Usia Merokok & Frekuensi & Persentase \\
\hline$<12$ & 7 & 21,2 \\
$12-30$ & 26 & 78,8 \\
$>30$ & - & - \\
\hline Total & $\mathbf{3 3}$ & $\mathbf{1 0 0}$ \\
\hline
\end{tabular}

Tabel 8. Distribusi Frekuensi Lama Merokok Responden Sebelum Menikah

\begin{tabular}{lcc}
\hline Lama Merokok & Frekuensi & Persentase \\
\hline$<5$ & 15 & 45,4 \\
$>5$ & 18 & 54,6 \\
\hline Total & 33 & 100 \\
\hline
\end{tabular}

\section{Distribusi Merokok Berdasarkan Usia}

Tabel 6. menunjukkan bahwa responden yang mempunyai kebiasaan merokok paling banyak pada kelompok usia 26-35 tahun dan 36-45 dengan masing-masing sebesar 15 dan 17 pasangan.

\section{Usia Pertama Kali Merokok}

Tabel 7 menunjukkan bahwa dari 33 responden yang merokok, sebagian besar $(78,8$ persen) responden pertama kali merokok pada usia antara 12-30 tahun.

\section{Lama Merokok}

Hasil wawancara dengan 33 responden yang mempunyai kebiasaan merokok tentang durasi lama merokok dapat dilihat pada tabel 8 .

Hasil penelitian menggambarkan untuk frekuensi lama merokok responden yang paling banyak sebelum menikah adalah lebih dari lima tahun yaitu sebesar 54,6 persen.

\section{Jumlah batang rokok}

Penelitian ini membagi jumlah batang rokok yang di hisap responden dalam tiga kelompok, yaitu 1-5 batang, 6-10 batang dan lebih dari 10 . Penelitian menunjukkan bahwa sebagian besar (63,6 persen) responden di Klinik Tiara Cita mengonsumsi rokok sejumlah 6-10 batang per hari (Tabel 9.).

\section{Konsumsi Alkohol}

Hasil penelitian menunjukkan bahwa dari 83 responden, lebih dari setengahnya (72,3 persen) tidak mengonsumsi alkohol, dapat dilihat lebih rinci pada Tabel 11.

\section{Terakhir Konsumsi Alkohol}

Hasil analisis Tabel 12. menunjukkan bahwa dari 23 responden yang mengonsumsi alkohol, frekuensi terakhir sebelum datang ke klinik paling banyak adalah 1-2 bulan yaitu sebesar 73,9 persen.

\section{Distribusi Konsumsi Alkohol Berdasarkan Usia}

Tabel 13. menggambarkan bahwa kelompok usia yang paling banyak mengonsumsi alkohol adalah usia 26-35 tahun yaitu sebanyak 12 responden dapat di lihat lebih rinci pada Tabel 12.

\section{Frekuensi konsumsi alkohol}

Tabel 9. Distribusi Frekuensi Jumlah Batang Rokok yang Dihisap

\begin{tabular}{lcc}
\hline Jumlah batang & Frekuensi & Persentase \\
\hline $1-5$ & 3 & 9,1 \\
$6-10$ & 21 & 63,6 \\
$>10$ & 9 & 27,3 \\
\hline Total & $\mathbf{3 3}$ & $\mathbf{1 0 0}$ \\
\hline
\end{tabular}

Tabel 11. Distribusi Frekuensi Mengonsumsi Alkohol

\begin{tabular}{lcc}
\hline Konsumsi Alkohol & Frekuensi & Persentase \\
\hline Ya & 23 & 27,7 \\
Tidak & 60 & 72,3 \\
\hline Total & $\mathbf{8 3}$ & $\mathbf{1 0 0}$ \\
\hline
\end{tabular}


Tabel 12. Distribusi Frekuensi Terakhir Mengonsumsi Alkohol

\begin{tabular}{lcc}
\hline $\begin{array}{l}\text { Terakhir konsumsi } \\
\text { alkohol }\end{array}$ & Frekuensi & Persentase \\
\hline Sampai saat ini & 2 & 8,7 \\
1 minggu terakhir & 2 & 8,7 \\
1-2 bulan terakhir & 17 & 73,9 \\
$>$ 12 bulan terakhir & 2 & 8,7 \\
\hline Total & $\mathbf{2 3}$ & $\mathbf{1 0 0}$ \\
\hline
\end{tabular}

Tabel 13. Distribusi Kebiasaan Mengonsumsi Alkohol berdasarkan Usia

\begin{tabular}{rrrr}
\hline \multirow{2}{*}{ Usia } & \multicolumn{2}{c}{ Konsumsi Alkohol } & \multirow{2}{*}{ Ya } \\
\cline { 2 - 3 } & \multicolumn{1}{c}{ Tidak } & \\
\hline $15-25$ & $3(13,1 \%)$ & $3(5 \%)$ & $6(7,2 \%)$ \\
$26-35$ & $12(52,2 \%)$ & $36(60 \%)$ & $48(57,9 \%)$ \\
$36-45$ & $8(34,7 \%)$ & $21(35 \%)$ & $29(34,9 \%)$ \\
\hline Total & $\mathbf{2 3 ( 2 7 , 7 \% )}$ & $\mathbf{6 0}(\mathbf{7 2 , 3 \% )}$ & $\mathbf{8 3 ( 1 0 0 \% )}$ \\
\hline
\end{tabular}

Tabel 14. Distribusi Frekuensi Mengonsumsi Alkohol

\begin{tabular}{lcc}
\hline $\begin{array}{l}\text { Frekuensi konsumsi } \\
\text { alkohol }\end{array}$ & Frekuensi & Persentase \\
\hline 1 minggu sekali & 1 & 4,5 \\
1 bulan sekali & 1 & 4,5 \\
$>$ 1 bulan & 3 & 13,1 \\
Jarang & 18 & 77,9 \\
\hline Total & $\mathbf{2 3}$ & $\mathbf{1 0 0}$ \\
\hline
\end{tabular}

Tabel 14 menginformasikan bahwa lebih dari setengah (77,9 persen) responden pasangan infertil jarang mengonsumsi alkohol.

\section{Takaran Konsumsi Alkohol}

Hasil penelitian menunjukkan dari 23 responden yang mengonsumsi alkohol, jumlah takaran untuk sekali mengonsumsi alkohol responden paling banyak adalah kurang dari satu slok/gelas yaitu sebanyak 14 responden. Lebih rinci dapat dilihat pada tabel 15 .

\section{Obesitas}

Responden dikatakan mengalami obesitas pada penelitian ini apabila mempunyai Indeks Masa Tubuh (IMT) lebih dari atau sama dengan
27. Lima puluh sembilan persen tidak mengalami obesitas (Tabel 16.).

\section{Distribusi Obesitas Berdasarkan Usia}

Tabel 17 menggambarkan bahwa kelompok usia yang paling banyak mengalami obesitas adalah diatas 25 tahun. Dengan masing-masing 26-35 tahun sebanyak 18 dan 36-45 tahun sebanyak 15.

\section{PEMBAHASAN}

\section{Karakteristik Responden}

Pendidikan mempengaruhi proses pembentukan sikap, dalam hal ini menjelaskan bahwa pendidikan mempengaruhi sikap seseorang dalam menangani suatu permasalahan dalam hidupnya. Hasil penelitian menunjukkan mayoritas responden pasangan infertil berpendidikan perguruan tinggi yaitu 66,3 persen atau sebanyak 55 responden an bekerja di sektor swasta ( 47 persen).

Tabel 15. Distribusi Frekuensi Takaran Konsumsi Alkohol Responden

\begin{tabular}{lcc}
\hline $\begin{array}{l}\text { Takaran konsumsi } \\
\text { alkohol }\end{array}$ & Frekuensi & Persentase \\
\hline 1 slok/gelas & 9 & 39,1 \\
$<1$ slok/gelas & 14 & 60,9 \\
\hline Total & $\mathbf{2 3}$ & $\mathbf{1 0 0}$ \\
\hline
\end{tabular}

Tabel 16. Distribusi Frekuensi Obesitas

\begin{tabular}{lcc}
\hline Obesitas & Frekuensi & Persentase \\
\hline Ya & 34 & 40,9 \\
Tidak & 49 & 59,1 \\
\hline Total & $\mathbf{8 3}$ & $\mathbf{1 0 0}$ \\
\hline
\end{tabular}

Tabel 17. Distribusi Obesitas Berdasarkan Usia

\begin{tabular}{rrrr}
\hline \multirow{2}{*}{ Usia } & \multicolumn{2}{c}{ Obesitas } & \multirow{2}{*}{ Frekuensi } \\
\cline { 2 - 4 } & \multicolumn{1}{c}{ Ya } & \multicolumn{1}{c}{ Tidak } & \\
\hline $15-25$ & $1(5,81 \%)$ & $4(8,23 \%)$ & $6(7,3 \%)$ \\
$26-35$ & $18(58,8 \%)$ & $28(57,1 \%)$ & $48(57,8 \%)$ \\
$36-45$ & $15(35,4 \%)$ & $17(34,7 \%)$ & $29(34,9 \%)$ \\
\hline Total & $\mathbf{3 4 ( 4 1 \% )}$ & $\mathbf{4 9 ( 5 9 \% )}$ & $\mathbf{8 3}(\mathbf{1 0 0 \% )}$ \\
\hline
\end{tabular}




\section{Kelompok Usia}

Penurunan kesuburan pada perempuan disebabkan beberapa hal. Semakin lanjut usia perempuan, semakin tipis sisa cadangan sel telur yang ada. Karena, indung telur juga semakin kurang peka terhadap hormon gonadotropin (hormon yang merangsang indung telur mengeluarkan hormon estrogen dan hormon progesteron). Semakin lanjut usia istri, semakin meningkat juga risiko untuk terjadinya infertilitas (Azhari, 2005).

Fase reproduksi merupakan waktu bereproduksi sehingga dapat mempunyai kemampuan untuk hamil yang dimulai setelah fase pubertas sampai sebelum fase menopause. Pada fase reproduksi, wanita mempunyai 400 sel telur. Semenjak wanita mengalami menarche sampai menopause, wanita mengalami menstruasi secara periodik yaitu pelepasan satu sel telur. Jadi, wanita dapat mengalami menstruasi sampai sekitar 400 kali. Diatas umur 35 tahun, kemampuan reproduksi wanita menurun drastis. Simpanan sel telur mulai berkurang pada umur 35 tahun dikarenakan mulai terjadi ketidakseimbangan hormon sehingga kesempatan wanita untuk bisa hamil menurun drastis dan kualitas sel telur yang dihasilkan pun menurun. Hal ini mengakibatkan tingkat keguguran meningkat. Pada kisaran umur 45 tahun sel telur sudah tidak berproduksi sehingga tidak terjadi menstruasi lagi dan kesempatan hamil sudah jauh meningkat (Aizid, 2012).

Pada pria dengan bertambahnya usia semakin dapat menyebabkan penurunan kesuburan di mana hanya sepertiga pria yang berusia diatas 40 tahun mampu menghamili istrinya dalam waktu 6 bulan, dibanding pria yang masih berusia di bawah 25 tahun. Kualitas sperma juga berbeda. Sperma yang sering disebut juga mani atau semen adalah ejakulat yang berasal dari seorang pria berupa cairan kental dan keruh, berisi secret dari kelenjar prostat, dan spermatozoa. Terdiri dari bagian cair dan bagian padat. Bagian yang cair ialah semen (air mani) dan yang padat adalah spermatozoa. Fungsi spermatozoa yaitu untuk mengantarkan material genetis jantan ke betina serta mengaktifkan program perkembangan telur (Kasdu, 2008).

Hasil penelitian menunjukkan bahwa kelompok usia responden lebih dari separuh
(57,8 persen) berusia antara $26-35$ tahun. Lebih lanjut penelitian Alam dan Hadibroto (2007), menyebutkan bahwa tingkat infertilitas wanita berbeda tergantung dari kelompok usia. Kelompok yang paling subur pada usia 20-29 tahun dengan tingkat 90 persen subur. Setelah itu, pada usia30-34 tahun angka ketidaksuburan naik menjadi 14 persen, usia 35-39 tahun meningkat lagi menjadi 20 persen, dan usia 40-44 tahun menjadi 25 persen.

\section{Kebiasaan Merokok}

Hasil penelitian menunjukkan bahwa, lebih dari setengah $(60,2 \%)$ total responden tidak memiliki kebiasaan merokok. Budiman (2011), menyebutkan bahwa ada hubungan antara kebiasaan merokok dengan kualitas sperma karena rokok mengandung zat berbahaya yang menyebabkan kerusakan oksidatif terhadap mitokondria, tingginya kerusakan pada morfologi sperma, serta menyebabkan keguguran dan secara jelas dapat meningkatkan risiko infertilitas pada pria maupun wanita merokok juga dapat merusak efek pengobatan kesuburan bahkan saat seseorang dalam keadaan hamil.

Asap rokok yang dihirup seorang perokok mengandung beberapa komponen yang berpotensi menimbulkan radikal bebas ke dalam tubuh, diantaranya karbon monoksida, karbon dioksida, oksida dan nitrogen dan senyawa hidrokarbon. Komponen partikel dalam asap rokok diantaranya nikotin, tar dan kadmiun. Kelebihan produksi radikal bebas atau oksigen yang reaktif (ROS, reactive oxygen species) dapat merusak sperma, dan ROS merupakan salah satu faktor penyebab infertilitas (Agarwal et al. 2003).

Kebiasaan merokok merupakan salah satu gaya hidup yang akan semakin menambah radikal bebas dalam tubuh sehingga lebih rentan mengalami infertilitas. Mitokondria dan plasma merupakan tempat produksi radikal bebas dalam tubuh. Proses produksi ini melibatkan enzim kreatinin kinase dan diaphorase. Radikal bebas menyebabkan kerusakan DNA dan akhirnya apopotosis sel sperma.

Hasil penelitian menunjukkan bahwa dari 33 responden yang merokok, sebagian besar ( 78,8 persen) responden pertama kali merokok pada usia antara 12-30 tahun dan sebagian besar 
(63,6 persen) responden mengonsumsi rokok sejumlah 6-10 batang per hari 54,6 persen. Responden dengan jangka waktu mengonsumsi rokok $>5$ tahun sebelum mereka menikah.

Pada perokok terdapat peningkatan level 8-hydroxydeoxyguanosine, penanda biokimia dan kerusakan oksidatif DNA sperma, yang menyebabkan terjadinya kerusakan DNA pada sperma. Spermatozoa tersebut mengalami kelainan struktur kromatin berupa single/doublestrand DNA breaks (Budiman, 2011).

Amaruddin (2012) menyebutkan bahwa pria yang merokok 10-20 batang per hari memiliki kecenderungan 7,2 kali untuk mengalami kualitas sperma abnormal dibandingkan pria yang tidak merokok. Pria yang merokok sebanyak 21-40 batang per hari memiliki kecenderungan mengalami kualitas sperma abnormal 27,7 kali dibandingkan pria yang tidak merokok.

Pada wanita yang mengonsumsi rokok, ditemukan kadar estradiol yang rendah dalam darah dan cairan folikular. Respons ovarium terhadap clomifen pada wanita yang merokok juga rendah, selain menyebabkan infertilitas juga menyebabkan aborsi dan angka keberhasilan kehamilan rendah. Hal tersebut diakibatkan efek negatif dari asap rokok seperti nikotin dan PAH terhadap gonadotropin, pembentukan corpus luteum, interaksi gamet, fungsi tuba, dan implantasi hasil konsepsi, sehingga bisa terjadi disfungsi tuba, abortus, kehamilan ektopik dan infertilitas.

\section{Konsumsi Alkohol}

Minuman keras (miras) merupakan minuman yang didalamnya terdapat kandungan alkohol seperti etanol berbahan psikoaktif yang menyebabkan penurunan kesadaran dan gangguan pada kesehatan. Mengonsumsi alkohol dalam jumlah yang berlebihan dapat menimbulkan dampak negatif di dalam kehidupan seperti kerusakan organ, dan gangguan sistem reproduksi (Ngadji, 2007).

Menurut Ress (2005), kandungan etanol yang terdapat dalam minuman keras dan mengonsumsi dalam dosis yang berlebihan dapat membahayakan motilitas spermatozoa dan mengurangi kemampuannya untuk bergerak menjadi lambat atau tidak melakukan perjalanan dalam garis lurus. Sel spermatozoa akan mengalami kesulitan untuk menembus lender serviks atau kulit luar sel telur. Akibatnya kemungkinan untuk membuahi sel telur juga tidak ada.

Menurut Amarudin (2012), etanol yang terdapat dalam minuman keras dapat menurunkan frekuensi gerakan flagel sehingga motilitas spermatozoa akan menurun. Hal ini diduga karena meningkatnya reaksi etanol di dalam tubuh mengakibatkan terjadinya kerusakan sel, sehingga produksi ATP sebagai bahan energi mitokondria rendah. Reaksi etanol dalam tubuh yang tinggi menimbulkan terbentuknya peroksida lipid pada membrane spermatozoa dapat menyebabkan kerusakan membrane spermatozoa. Peroksida lipid tersebut berasal dari reaksi asam lemak tak jenuh dengan etanol yang banyak terdapat pada membran spermatozoa. Kerusakan sel spermatozoa dapat terjadi karena enzim pertahanan terhadap reaksi etanol dalam sitoplasma spermatozoa tidak cukup banyak untuk menurunkan reaksi etanol.

Alkohol dapat mengganggu fungsi sel Leydig dengan sintesis testosteron sehingga menyebabkan kerusakan pada membran basalis. Alkohol juga dapat memperburuk kualitas sperma, jumlah sperma rendah, encer, morfologi sperma abnormal serta menurunkan kadar zinc yang berguna untuk membentuk lapisan luar dan ekor sperma serta melindungi dari kerusakan oxidative dan membantu menghentikan aglutinasi dan jika dalam jumlah banyak dapat menurunkan fungsi seksual melalui penghambatan biosintesis (Ambarwati, 2009).

Sistem reproduksi pria terdiri dari hipotalamus, kelenjar pituitari anterior, dan testis. Alkohol dapat mengganggu fungsi dari masing-masing komponen sehingga menyebabkan impotensi, infertilitas dan mengurangi karakteristik seksual sekunder.

Hasil penelitian menunjukkan 72,3 persen tidak mengonsumsi alkohol. Jarkko (2006), menjelaskan bahwa konsumsi alkohol dalam jumlah moderat dapat mempengaruhi kualitas air mani serta secara serius mempengaruhi proses spermatogenesis.

Alkohol berhubungan dengan gangguan kesehatan reproduksi seperti impotensi dan atropi testis, spermatogenesis dan memiliki efek 
merugikan pada reproduksi laki-laki, hormon dan kualitas sperma. Sebuah kasus kontrol studi yang dilakukan di Jepang menunjukkan bahwa alkohol secara signifikan lebih umum pada infertil pria dibandingkan pada kontrol. Alkohol paparan in vitro menginduksi penurunan motilitas sperma dan morfologi, dan respons berhubungan dengan dosis. Selain itu, risiko aneuploidi sperma $\mathrm{XY}$ adalah lebih besar pada peminum alkohol dibandingkan dengan bukan peminum (Budiman, 2011).

Penelitian Ahsan (2012) menjelaskan bahwa pria yang memiliki kebiasaan konsumsi alkohol memiliki risiko 13.409 kali lebih besar untuk mengalami keterlambatan konsepsi (infertilitas) pasangan suami istri pada laki-laki bila dibandingkan dengan responden yang tidak mengonsumsi alkohol, atau dapat disimpulkan bahwa kebiasaan mengonsumsi alkohol merupakan faktor risiko terhadap kejadian keterlambatan konsepsi (infertilitas) pasangan suami istri pada laki-laki.

\section{Obesitas}

Faktor risiko kejadian infertilitas lainnya adalah obesitas. Hasil penelitian menunjukkan 59 persen responden tidak mengalami obesitas. Selanjutnya kelompok usia yang paling banyak mengalami obesitas adalah di atas 25 tahun. Andon (2015), menjelaskan bahwa obesitas pada wanita memiliki risiko 78 persen lebih besar mengalami infertilitas dibandingkan dengan wanita yang tidak obesitas. Pria obesitas memiliki risiko 49 persen lebih tinggi dibandingkan yang berat badan normal sedangkan pasangan usia subur yang keduanya obesitas memiliki risiko 2.74 kali untuk mengalami infertilitas dibandingkan pasangan subur yang tidak obesitas.

Penelitian Juwarnis (2009), juga menyebutkan bahwa obesitas mempunyai hubungan dengan kejadian infertilitas. Pasangan usia subur yang mengalami obesitas mempunyai peluang 13,6 kali untuk mengalami infertilitas dibanding pasangan yang tidak obesitas. Beberapa kasus infertilitas pada pria yang disebabkan obesitas mempunyai hubungan dengan tingginya estrogen yang dihasilkan yang disebabkan persentase lemak yang berlebih dibanding dengan pria yang memiliki berat badan normal. Obesitas mengakibatkan rendahnya produksi sperma, sperma yang abnormal, disfungsi ereksi dan kemandulan (Sallmen M, dkk, 2006).

Hasina (2011) menyebutkan bahwa obesitas merupakan salah satu faktor pada infertilitas. Jika seorang memiliki berat badan yang berlebih (over weight) atau memiliki lemak tubuh 10$15 \%$ dari persentase lemak tubuh normal atau mengalami obesitas, maka seseorang tersebut kemungkinan besar akan menderita gangguan keseimbangan hormon dan pertumbuhan folikel di ovarium meningkat yang disebut Polycistic Ovarium Syndrome (PCOS).

Pada wanita yang memiliki persentase lemak tubuh tinggi terjadi peningkatan produksi androstenedion yang merupakan androgen yang berfungsi sebagai prekusor hormon reproduksi. Androgen digunakan untuk memproduksi estrogen di dalam tubuh dengan bantuan enzim aromatase. Proses aromatisasi androgen menjadi estrogen ini terjadi di sel-sel granulosa dan jaringan lemak. Semakin banyak persentase jaringan lemak tubuh, semakin banyak pula estrogen yang terbentuk yang kemudian dapat mengganggu keseimbangan hormon di dalam tubuh sehingga menyebabkan gangguan menstruasi.

Gangguan siklus menstruasi tersebut diakibatkan karena adanya gangguan umpan balik dengan kadar estrogen yang selalu tinggi sehingga kadar Follicle Stimulating Hormone (FSH) tidak mencapai puncak. Pertumbuhan folikel terhenti sehingga tidak terjadi ovulasi. Keadaan ini berdampak pada perpanjangan siklus menstruasi (oligomenore) ataupun kehilangan siklus menstruasi (amenore) (Alaa, 2015).

\section{SIMPULAN DAN SARAN}

\section{Simpulan}

Sebagian besar responden sebagian besar mengalami infertilitas primer ( 77,1 persen), kelompok usia responden lebih dari separuh $(57,8$ persen) berusia antara 26-35 tahun. Pendidikan terakhir responden sebagian besar (66,3 persen) adalah PT dan jenis pekerjaan yang paling banyak adalah swasta 
Responden melakukan perilaku berisiko sebesar 39,8 persen untuk kebiasaan merokok, mengonsumsi alkohol (27,7 persen ), dan obesitas (40,9 persen).

\section{Saran}

Pihak klinik diharapkan untuk dapat memberikan informasi tentang gaya hidup dan beberapa perilaku berisiko yang menjadi salah satu faktor kejadian infertilitas.

Pasangan suami istri yang keduanya atau salah satu diantaranya mengalami obesitas bisa menjaga berat badan yang ideal dengan menerapkan pola hidup sehat.

\section{DAFTAR PUSTAKA}

Agarwal A, Saleh RA, Bedaiwy MA.2003. Role of reactive oxygen species ini the pathophysiology of human reproduction. Fertil Steril. 79:829843

Ahsan, Buraerah Abd. Hakim, Muh. Tamar. 2012. Faktor Risiko Yang Mempengaruhi Keterlambatan Konsepsi (Infertilitas) Pasangan Suami Istri pada Laki-laki di Kecamatan Palu Utara Kota Palu. FKM UNHAS.

Alaa, H. J. 2015. A Study of the correlations of some sex hormone with obesity secondary infertility. Department of Chemistry, college of science, Al Nahrun University. Vol. 18(2), June, 2015. Pp. 44-49.

Alam, S. \& Hadibroto, I. 2007. Infertil.Jakarta: PT. Gramedia Pustaka Utama.

Amarudin. 2012. Tesis. Pengaruh Merokok Terhadap Kualitas Sperma Pada Pria dengan Masalah Infertilitas Studi Kasus Kontrol di Jakarta tahun 2011.Univeritas Indonesia. Jakarta.

Ambarwati, P. 2009. Asuhan Kebidanan Komunitas. Yogyakarta: Nuha Medika.

Andon, H. 2015. Reproduksi dan Infertilitas dalam Praktek Sehari-hari. Jakarta: Badan Penerbit Fakultas Kedokteran UI.

Azhari, A. 2005. Pengobatan Alternatif Dan Pijat Refleksi. Surabaya: Pustaka Hikmah Perdana.
Aizid, R. 2012. Mengatasi Infertilitas (Kemandulan). Jogjakarta: Flash Books.

Budiman. 2011. Skripsi. Hubungan Usia, Kebiasaan Merokok, Kebiasaan Minum Alkohol, Dan Konsumsi Obat-obatan dengan Kualitas Sperma Di Fertility Centre RSIA Melinda Bandung.

Hasina, M. 2011. "Factors Associated with Secondary Infertility". Department of Community Medicine, Ibrahim Medical College, Dhaka Bangladesh.

Jsuwarnis, Y. 2009. Faktor Eksternal Yang Berhubungan Dengan Kejadian Infertilitas Pada Ibu Di RSUP DR. M. Djamil Padang Tahun 2008. Fakultas Kedokteran. Universitas Andalas

Kasdu, D. 2008. Solusi Problem Wanita Dewasa. Jakarta: Puspa Swara, Anggoru IKAPI.

Koes, I. 2014. Panduan Lengkap Biologi Reproduksi Manusia untuk Paramedis dan Nonmedis. Bandung: Alfabeta.

Kusmiran, E. 2013. Reproduksi Remaja dan Wanita. Jakarta: Salemba Medika.

Ngadji, A. 2007. Pengaruh Pemberian Etanol Per oral terhadap Gambaran Histologik Sel-Sel Spermatogenik dan Sel Leydig Pada Testis Tikus Putih. JIPTUNAR. Surabaya.

Ress, T.J. 2005. The Toxicology Of Male Reproduction. Literature Review in Applied Toxicology. Portsmouth University

Sa'adah, Najakhatus. 2016. Perbedaan Jenis Infertilitas Berdasarkan Karakteristik, Kebiasaan Merokok, Konsumsi Alkohol dan Obesitas (Studi Pada Pasangan Infertil di Klinik Fertilitas dan Bayi Tabung Tiara Cita RS. Putri Surabaya). Surabaya: Universitas Airlangga.

Saleh RA, Agarwal A., Nada EA., El-Tonsy MH., et al.2002. Negative Effects Of Increased Sperm DNA Damage in Relation Seminal Oxidative Stress in Men With Idiopthic And Male Factor Infertility. Fertil Tsteril 79(3):1597-1605.

Sallmen M, dkk. 2006. Reduced fertility among overweight and obese men. Epidemiology. 